\title{
PEMIKIRAN PENDIDIKAN ISLAM MOHAMMAD NATSIR
}

\author{
Saskhia Rahma Mouli Friani \\ Universitas Islam Negeri Sultan Syarif Kasim Riau \\ E-mail: saskhiamouli@gmail.com
}

\begin{abstract}
Abstrak
Membicarakan pendidikan Islam berarti membicarakan masalah diri manusia sendiri sebagai makhluk Tuhan yang dipersiapkan untuk menjadi khalifah-Nya di muka bumi dalam kerangka mengabdi kepada-Nya. Salah satu tantangan pendidikan Islam adalah masih terjadinya dikotomi ilmu. Artinya, terjadi pemisahan antara ilmu-ilmu agama dan ilmu-ilmu dunia (profan) yang saling menafikan satu sama lain. Cara pandang semacam ini jelas akan berpengaruh besar terhadap sikap seseorang dalam memandang ilmu. Berangkat dari itulah penulis kemudian membahas kembali tentang pemikiran tokoh dan intelektual muslim Indonesia yang mencoba untuk merumuskan pendidikan Islam sesuai dengan harapan agama, bangsa dan Negara, yaitu Muhammad Natsir. Maka dari itu, penulis mengambil judul "Pemikiran Pendidikan Islam Mohammad Natsir". Penelitian ini bertujuan untuk mendapatkan informasi mengenai konsep pendidikan Islam menurut Muhammad Natsir. Penelitian ini menggunakan metode penelitian kualitatif dengan jenis kepustakaan dan dengan pendekatan historis. Sedangkan metode pengumpulan data menggunakan metode dokumentasi, serta analisis datanya adalah dengan metode content analysis. Dengan kerangka itu, dapat diketahui bahwa konsep pendidikan Islam menurut Muhammad Natsir yaitu konsep pendidikan yang memadukan antara pendidikan umum dan pendidikan agama, kesinambungan itu dibuktikan dengan tidak mempertentangkan antara Barat dan Timur. Islam hanya mengenal perbedaan antara hak dan bathil. Semua yang hak dapat diterima, meskipun datangnya dari Barat, dan semua yang bathil akan disingkirkan walaupun datangnya dari Timur. Dengan begitu, akan tercipta anak didik yang mementingkan ruhani dan jasmaninya.
\end{abstract}

Keywords: Konsep, Pendidikan Islam, Mohammad Natsir 


\section{Abstract}

Discussing the issue of Islamic education means talking about man himself as a creature of God which prepared to be a caliph (leader) on earth in order to serve the God. One of the challenges of Islamic education is still the dichotomy of science. It's meaning, there's a separation between religious sciences and world sciences that get rid of each other. This perspective will obviously have a big impact on one's attitude in looking at science. Based on that point, the author discusses more about thought of figure and Indonesian muslim intellectuals who tried to formulate Islamic education in line with the religion's hope, nation and state, he is Muhammad Natsir. Therefore, the author has taken the title "Pemikiran Pendidikan Islam Mohammad Natsir". This research aims to get information about the concept of Islamic education according to Muhammad Natsir. This research already used qualitative research methods with type of literature and historical approach. And documentation for method of collecting data, and content analysis for data analysis. By its framework, can be seen that the concept of Islamic education according to Muhammad Natsir is the concept of education that combines between general education and religious education, sustainability is evidenced by not dispute between west and east. Islam only knows the difference between right and falsehood. All the rights are acceptable although coming from the west, and all falsehood will be removed although coming from the east. Therefore, will be create students who are concerned their spiritual and their physical.

Key words: Konsep, Pendidkan Islam, Mohammad Natsir

\section{Pendahuluan}

Pendidikan merupakan bagian yang tidak dapat dipisahkan dari hidup dan kehidupan manusia. Sejak manusia menghendaki kemajuan dalam kehidupan, maka sejak itu timbul gagasan untuk melakukan pengalihan, pelestarian dan pengembangan kebudayaan melalui pendidikan. Proses pendidikan sebenarnya telah berlangsung lama, yaitu sepanjang sejarah manusia itu sendiri, dan seiring pula dengan perkembangan sosial budayanya. Secara umum aktivitas pendidikan sudah ada sejak manusia diciptakan. Betapa pun sederhana bentuknya, manusia 
memang melakukan pendidikan sebab manusia bukan termasuk makhluk instintif ${ }^{1}$.

Dewasa ini dalam dunia pendidikan ada istilah dikotomi keilmuan, antara ilmu agama dan ilmu umum. Dikotomi tersebut menghasilkan kesan bahwa pendidikan agama berjalan tanpa dukungan iptek dan sebaliknya pendidikan umum hadir tanpa sentuhan agama.

Islam adalah agama yang mengajarkan pandangan hidup (way of life) bagi seluruh umat manusia yang menekankan pentingnya menjaga keseimbangan antara dunia dan akhirat, jasmani dan rohani, material dan spiritual, dan seterusnya. Islam melihat manusia sebagai makhluk yang dimuliakan Tuhan di muka bumi dan harus melakukan perannya sebagai khalifah dan hamba Allah SWT melalui karya-karya yang bermanfaat bagi kehidupan seluruh umat manusia ${ }^{2}$.

Adalah Muhammad Natsir, seorang pahlawan nasional yang kiprahnya dalam memajukan bangsa ini, khususnya umat Islam di waktu lampau telah diakui oleh berbagai kalangan. Beliau juga dikenal sebagai seorang aktivis pendidik bangsa yang telah menorehkan episode sejarahnya di Indonesia sejak awal kemerdekaan hingga masa orde baru. Pemikirannya banyak digali dan dijadikan titik tolak kebangkitan umat Islam dalam berbagai macam bidang.

Natsir melihat bahwa masalah pokok untuk mengatasi keterbelakangan dalam pendidikan adalah dengan merombak sistem dan kurikulum serta konsep pendidikan yang dikotomis kepada sistem yang integrated antara ilmu agama dan umum, dan dengan mempersiapkan guru yang komitmen-profesional dan dapat menjadi teladan bagi peserta didik.

Menurut Natsir, bahwa Islam bukan sekedar agama dalam pengertian yang sempit yang mengatur hubungan manusia dengan Tuhan saja, melainkan juga mengatur hubungan manusia dengan manusia. Dari pertimbangan yang telah diutarakan diatas, terlihat bahwa studi mengenai Mohammad Natsir dan pemikirannya tentang pendidikan Islam merupakan bidang yang amat menarik dan penting untuk diteliti serta cukup beralasan, maka penulis berusaha menganalisis pemikiran Mohammad Natsir, serta membuat format dari gagasan tersebut yang dikemas dalam suatu rumusan: Bagaimana konsep Pendidikan

${ }^{1}$ Jalaluddin, Teologi Pendidikan (Jakarta: PT. Raja Grafindo Persada, 2003), hlm. 113-114.

${ }^{2}$ Abuddin Nata, Tokoh-Tokoh Pembaruan Pendidikan Islam di Indonesia (Jakarta: PT. Raja Grafindo Persada, 2005), hlm. 72. 
Islam menurut Muhammad Natsir. Untuk menjawab permasalahan ini maka akan dibahas pemikiran Muhammad Natsir mengenai: (a) aspek pendidikan islam (b) tujuan pendidikan Islam, (c) kurikulum pendidikan Islam, (d) metode pendidikan Islam, (e) aktualisasi dalam pendidikan Indonesia.

Setelah melakukan pencarian terkait dengan artikel ini, terdapat beberapa penelitian terdahulu yang berkaitan dengan penelitian ini, antara lain:

1. Penelitian Aulia Annisa (2019) dengan judul: Pemikiran Mohammad Natsir Tentang Pendidikan Islam Dan Perannya Dalam Mendorong Pembaharuan Pendidikan Islam Di Indonesia.

2. Penelitian Ahmad dan Hayati (2018) dengan judul: Analisis Pemikiran M. Natsir tentang Pendidikan Islam di Indonesia.

3. Penelitian Mislaini (2017) dengan judul: Pemikiran Mohammad Natsir tentang Pendidikan Islam.

4. Penelitian Puspita Lestari (2016) dengan judul: Konsep Pendidikan Islam Menurut Mohammad Natsir dan Aktualisasinya dalam Pendidikan Indonesia.

5. Penelitian La Rajab (2016) dengan judul: Konsep Pendidikan Islam Mohammad Natsir.

\section{Metode}

Dalam menyusun artikel ini, peneliti menggunakan jenis penelitian kepustakaan (library research). Yaitu serangkaian kegiatan yang berkenaan dengan pengumpulan data pustaka, membaca, mencatat serta mengolah bahan penelitian. Dan juga menggunakan pendekatan kualitatif, dimana prosedur penelitian yang menghasilkan data deskriptif berupa kata-kata tertulis atau lisan yang disampaikan dari orang-orang dan perilaku yang diamati. Karena jenis penelitian ini adalah kepustakaan, maka data- data yang diperoleh itu berupa buku-buku, dokumen, catatan, artikel dan sumber-sumber lainya dari internet yang terkait dengan permasalahan yang diangkat penulis.

Dengan mempelajari Pemikiran Pendidikan Islam Mohammad Natsir, mahasiswa atau pembaca dapat mengetahui:

1. Dapat mengetahui biografi Mohammad Natsir dan karya-karyanya 
2. Dapat mengetahui pemikiran dan konsep-konsep Mohammad Natsir tentang Pendidikan Islam.

\section{Pembahasan}

\section{Profil Mohammad Natsir}

Muhammad Natsir lahir di Jembatan Berukir, Alahan Panjang Kabupaten Solok, Sumatera Barat, pada hari Jum'at, 17 Jumadil Akhir 1326 Hijriah, bertepatan dengan 17 Juli 1908 Masehi. Ibunya bernama Khadijah, sedangkan ayahnya bernama Muhammad Idris Sutan Saripado, seorang pegawai rendah yang pernah menjadi juru tulis pada kantor kontroler di Maninjau dan sipir penjara di Sulawesi Selatan. Ia memiliki tiga orang saudara kandung, masingmasing bernama Yukinan, Rubiah dan Yohanusun. Di desa kelahirannya itu, Natsir kecil melewati masa-masa sosialisasi keagamaan dan intelektualnya ${ }^{3}$.

Riwayat pendidikan Muhammad Natsir dimulai dari Sekolah Rakyat (SR) di Maninjau Sumatera Barat hingga kelas dua. Sekolah ini merupakan sekolah swasta yang mempergunakan bahasa Melaya sebagai bahasa pengantar. Ketika ayahnya dipindahtugaskan ke Bekeru, Muhammad Natsir mendapat tawaran dari mamaknya, Ibrahim, untuk pindah ke Padang agar dapat menjadi siswa di Holland Inlandse School (HIS) Padang. Tawaran tersebut diterima oleh Muhammad Natsir dengan penuh antusias. Namun HIS Padang menolaknya, dengan pertimbangan Muhammad Natsir adalah seorang anak pegawai rendahan. Untungnya saat itu di Padang sudah ada HIS Adabiyah, sebuah sekolah swasta yang menyelenggarakan pendidikan bagi anak-anak negeri. Muhammad Natsir diterima sebagai murid di HIS Adabiyah itu. Selama lima bulan belajar di HIS Adabiyah Padang Panjang itu, Muhammad Natsir tinggal bersama dengan makciknya, Ibrahim. Selain belajar di HIS, pada pagi hari, Muhammad Natsir juga belajar di Sekolah Diniyah pada waktu sore dan belajar mengaji pada malam hari. Setelah lulus dari HIS, Muhammad Natsir mengajukan permohonan untuk mendapat beasiswa dari MULO (Meer Uitgebreid Lager Orderwijs) dan ternyata lamarannya itu diterima. Di MULO Padang inilah Muhammad Natsir mulai aktif dalam organisasi.

Aktivitas Muhammad Natsir semakin berkembang ketika menjadi siswa di Algememe Midelbare School (AMS) di Bandung. Di kota ini ia mempelajari agama

${ }^{3}$ Abuddin Nata, Tokoh-Tokoh Pembaruan Pendidikan Islam di Indonesia (Jakarta: PT. Raja Grafindo Persada, 2005). 
secara mendalam serta berkecimpungan dalam bidang politik, dakwah dan pendidikan. Di tempat ini pula Muhammad Natsir berjumpa dengan A. Hasan (1887-1958), seorang tokoh pemikir radikal dan pendiri Persatuan Islam (Persis). Natsir mengakui bahwa A. Hasanlah yang memengaruhi alam pikirannya. Hal ini karena Muhammad Natsir tertarik pada kesederhanaan A. Hassan, juga kerapihan kerja dan kealimannya4. Pada tahun 1932-1942, beliau memimpin Lembaga Pendidikan Islam (PENDIS) yang menjadi cikal bakal lahirnya Universitas Islam Bandung (UNISBA), yang saat menjadi universitas terpandang di kota Bandung. Setelah matang membangun Pendis, Natsir mengarahkan andilnya untuk membangun perguruan Islam lainnya. Beliau melakukan adanya koordinasi dan penyelarasan program pendidikan perguruan Islam bakal melahirkan institusi pendidikan Islam yang memiliki keseragaman dasar dan cita-cita.

Guna merealisasikan tujuannya ini, beliau menyeru perguruan dan institusi pendidikan Islam di Indonesia untuk membentuk wadah bersama yang diberi nama Perikatan Perguruan-Perguruan Muslim (PERMUSI). Beliau juga tercatat sebagai penggagas di balik berdirinya Badan Kerja Sama Perguruan tinggi Islam Swasta (BKS PTIS) yang kini memiliki anggota lebih dari 500 PTIS se Indonesia. Dari gagasan Muhammad Natsir lahirlah kampus-kampus Islam yang memiliki nama besar, seperti Universitas Islam Indonesia (UII) di Yogyakarta, Universitas Islam Sumatera Utara (UISU) di Medan, Universitas Islam Bandung (UNISBA) di Bandung, Universitas Muslim Indonesia (UMI) di Makasar, Universitas Islam Sultan Agung (UNISSULA) di Semarang, Universitas Islam Riau (UIR) di Riau, Universitas Al-Azhar Indonesia, dan LPDI Jakarta yang kini menjadi Sekolah Tinggi Ilmu Dakwah (STID) Muhammad Natsir.

Muhammad Natsir berpulang ke rahmatullah pad tanggal 6 Februari 1993 Masehi bertepatan dengan 14 Sya'ban 1413 Hijriah di rumah sakit Cipto Mangun Kusumo Jakarta dalam usia 85 tahun dengan meninggalkan enam orang anak dari pernikahannya dengan Nurhanar, yaitu; Siti Muchlisoh (20 Maret 1936), Abu Hanifah (29 April 1937), Asma Farida (17 Mei 1941). Hasnah Faizah (5 Mei 1941), Aisyatul Asrah (20 Mei 1942), dan Ahmad Fauzi (26 April 1944).

\section{Karya Mohammad Natsir}

Mohammad Natsir, selain sebagai sosok aktivis pergerakan yang menggerakkan berbagai organisasi pergerakan, adalah juga seorang ilmuwan

${ }^{4}$ Ardian,Husaini, Muhammad Natsir:Pahlawan Pendidik Teladan. Republika (2010). 
yang banyak menuangkan pemikirannya dalam bentuk tulisan, baik di majalah harian, maupun buku-buku. Buku-buku tersebut antara lain sebagai berikut:

a. Islam Sebagai Ideologi, diterbitkan tahun 1951 di Jakarta. Buku ini berisi ajaran Islam dalam kedudukannya sebagai pedoman hidup manusia pada umumnya dan umat Islam khususnya.

b. Agama dan Negara, Falsafah Perjuangan Islam, diterbitksn di Medan tahun 1951, berbicara tentang hubungan agama dan negara.

c. Capita Selekta, diterbitkan di Jakarta berisi dua jilid, jilid I ditulis pada tahun 1954 dan jilid II pada tahun 1957. Kedua buku ini mengulas tentang berbagai hal yang berhubungan dengan pemikiran umum mengenai politik, ekonomi, pendidikan, dan sosial budaya.

d. The NewMorality (Moral Baru), terbit tahun 1969 di Surabaya. Buku yang mengupas tentang pengaruh paham sekuler terhadap kehidupan manusia.

e. Islam dan Kristen Di Indonesia, diterbitkan oleh CV. Bulan Sabit di Bandung pada tahun 1969, berisi tentang uraian mengenai keberadaan Islam dan dalam menghadapi upaya kekristenan di Indonesia.

f. Di Bawah Naungan Risalah, buku yang berisi tentang bimbingan Islam dalam kehidupan manusia, diterbitkan di Jakarta tahun 1971.

g. Ikhtaru, al-Khas Sabilani, Addi nu aw la Dinu, buku yang mengulas konsistensi sikap manusia sesudah beragama, diterbitkan di Jeddah tahun 1971.

h. Dakwah dan Pembangunan, buku ini memuat tentang relevansi dakwah Islam dan konstribusi ajaran Islam terhadap pembangunan Nasional, diterbikan tahun 1974 di Bangil.

i. Dari Masa ke Masa, buku yang memuat perjalanan hidup seseorang kaitannya dengan kesadaran memanfaatkan waktu yang ada. Buku ini ditulis pada tahun 1975 dan diterbitkan di Jakarta.

j. Buku Pendidikan Moral Pancasila dan Mutiara yang Hilang, buku yang berisi tentang koreksi terhadap penyimpangan materi buku PMP yang bermuara pada pendangkalan ajaran akidah Islam.

k. Mempersatukan Umat Islam, dan masih banyak buku lainnya baik yang berbahasa Indonesia maupun asing (bahasa Arab dan Inggris). Jika diperhatikan, hampir semua karya Natsir tidak ada yang secara spesifik membahas tentang pendidikan, lebih menekankan pada kajian Islam dan elaborasinya. Oleh karena itu, tidak heran jika masyarakat pada umumnya mengenal Natsir lebih sebagai 
pejuang atau da'i ketimbang ahli pendidikan. Namun demikian, ada pula beberapa bagian pemikiran Natsir yang menyinggung tentang pendidikan, terutama dalam buku Capita Selekta, juga dalam buku Pendidikan, Pengorbanan, Kepemimpinan, Primordialisme, dan Nostalgia.

\section{Pemikiran Mohammad Natsir tentang Pendidikan Islam}

Adapun pemikiran Muhammad Natsir tentang Pendidikan Islam ialah:

\section{a). Asas/ Pondasi Pendidikan Islam}

Aspek/Pondasi Pendidikan Islam Aspek pendidikan merupakan pemikiran yang paling krusial dan paling utama dalam pandangan Mohammad Natsir. Hal itu terlihat secara eksplisit dalam pidatonya pada saat rapat Persatuan Islam di Bogor bertepatan tanggal 17 Juni 1974. Dalam kesempatan itu ia mengatakan:

"Tak ada bangsa jang terbelakang mendjadi madju, melainkan sesudahnja mengadakan dan memperbaiki didikan anak-anak dan pemuda-pemuda mereka. Bangsa Djepang, satu bangsa Timur jang sekarang djadi buah mulut orang seluruh dunia lantaran madjunja, masih akan terus tinggal dalam kegelapan sekiranja mereka tidak mengatur pendidikan bangsa mereka; kalau sekiranja mereka tidak membukakan pintu negaranja jang selama ini tertutup rapat, untuk orang-orang pintar dan ahli-ahli ilmu negeri lain jang akan memberi didikan dan pengetahuan kepada pemuda-pemuda mereka di samping mengirim pemuda-pemuda mereka ke luar negeri mentjari ilmu"s.

Beranjak dari kutipan di atas, terlihat secara jelas alur pemikiran Mohammad Natsir yang cukup ekspektatif. Kemajuan suatu bangsa menurut penggagas Dewan Dakwah Islamiyah Indonesia ini adalah upaya yang paling ampuh dalam mengangkat kondisi umat yang terbenam dalam lumpur keterbelakangan. Oleh karena itulah barangkali, makanya ia lebih mnegutamakan jadi guru untuk mendidik umat ketimbang menjadi pegawai lainnya. Di samping itu, melalui teks pidatonya juga menggambarkan keluasan wawasan Mohammad Natsir dan keterbukaan pemikirannya tentang pendidikan. Pendidikan Islam diyakininya tidak akan maju-majunya selama masih bersifat inklusif konservatif seperti selama ini dan tidak membuka pintu untuk menerima pemikiran orangorang pintar dari luar sekalipun itu berasal dari orang-orang Barat. Dalam analisa Mohammad Natsir, kemunduran dan kemajuan suatu bangsa, tidak tergantung kepada ketimuran dan kebaratan, tidak tergantung kepada putih, kuning atau

${ }^{5}$ Mohammad Natsir, Capita Selekta, jilid I \& II.( Jakarta: Bulan Bintang,1973). 
hitamnya warna kulit, akan tetapi bergantung kepada ada atau tidaknya sifat-sifat atau bibit - bibit kesanggupan dalam salah satu umat ${ }^{6}$.

Dengan demikian, pendidikan Islam itu harus dinamis dan diselaraskan dengan ajaran Islam yang bersifat universal. Mencermati pidato dan dokumentasi tertulis Mohammad Natsir, dapat dianalisis pemikirannya tentang asas ataupun pondasi pendidikan Islam. Dalam salah satu ceramahnya ia berkata: "Memang, kalau kita buka al-Qurân, kita tidak akan bertemu di dalamnya petunjukpetunjuk untuk merancangkan Anggaran Belanja Negara yang diatur oleh Islam ialah dasar-dasar dan pokok-pokok mengatur masyarakat, manusia yang tidak berubah-rubah kepentingan dan keperluannya selama manusia masih bersifat manusia, baik manusia di zaman onta ataupun manusia zaman kapal terbang..." Mengamati cuplikan pidato yang disampaikan Mohammad Natsir itu, maka dapat dideskripsikan bahwa dasar atau pondasi pendidikan Islam adalah al-Qurân. AlQurân menurutnya adalah prinsip dasar yang berisikan pokok-pokok dalam mengatur kehidupan masyarakat. Sedangkan yang berkenaan dengan keduniaan yang selalu bertukar dan berubahubah sesuai dengan tempat dan keadaannya diserahkan kepada manusia. Dengan demikian, yang menjadi asas pendidikan itu adalah: al-Qurân, Hadits Nabi SAW, dan juga pemikiran manusia itu sendiri (ijtihad) ${ }^{7}$.

\section{b). Tujuan Pendidikan Islam}

Tujuan pendidikan Islam yang ingin dicapai oleh Mohammad Natsir adalah membentuk manusia yang beriman, bertaqwa, berakhlak mulia, maju dan mandiri sehingga memiliki ketahanan rohaniah yang tinggi serta mampu beradaptasi dengan dinamika perkembangan masyarakat ${ }^{8}$. Selain itu bahwa tujuan manusia adalah untuk mendapatkan kebahagiaan hidup di dunia dan di akhirat, tidak akan diperoleh dengan sempurna kecuali dengan keduanya. Pendidikan Islam tidak bisa dipisahkan dari kehidupan manusia. Tujuan pendidikan Islam sama dengan tujuan kehidupan manusia, tujuan ini tercermin dalam al Qur'an Surat Al-An'am:162.

${ }^{6}$ Ajip Rosidi, Sebuah Biografi. (Jakarta: Gimukti Pusaka,1990).

${ }^{7}$ Ramayulis dan Samsul Nizar, Ensiklopedi Tokoh Pendidik Islam;Mengenal tokoh Pendidikan Islam di Indonesia. (Quantum Teaching,2001).

${ }^{8}$ Abibullah Djaini, Pemikiran dan Perjuangan Mohammad Natsir. (Jakarta: Pustaka Firdaus,1996) 
"Katakanlah: 'Sesungguhnya shalatku, ibadatku, hidupku dan matiku hanyalah untuk Allah, Rabb semesta alam'." (QS. Al-An'am: 162)

Bagi Muhammad Natsir, fungsi tujuan pendidikan adalah memperhambakan diri kepada Allah SWT semata yang bisa mendatangkan kebahagiaan bagi penyembahnya. Hal ini juga yang disimpulkan oleh Abuddin Nata, tentang tujuan pendidikan Islam menurut Muhammad Natsir, bahwa pendidikan Islam ingin menjadikan manusia yang memperhambakan segenap rohani dan jasmaninya kepada Allah SWT. Hal ini sesuai dengan konsep Islam terhadap manusia itu sendiri. Bahwa mereka diciptakan oleh Allah untuk menghambakan diri hanya kepada Allah semata. Oleh karenanya segala usaha dan upaya manusia harus mengarah ke sana, yaitu Firman Allah Ta'ala:

"Dan Aku tidak menciptakan jin dan manusia melainkan supaya mereka menyembah-Ku." (QS. Adz-Dzariyaat: 56).

Selanjutnya Natsir mengatakan bahwa apabila manusia telah menghambakan diri sepenuhnya kepada Allah, berarti is telah berada dalam dimensi kehidupan yang menyejahterakan di dunia dan membahagiakan diakhirat. Menurut Natsir dalam menetapkan tujuan pendidikan Islam, hendaknya mempertimbangkan posisi manusia sebagai ciptaan Allah yang terbaik dan sebagai khalifah di muka bumi ${ }^{9}$. Perkataan menyembah-Ku sebagaimana terdapat dalam potongan surat az Dzariyat tersebut diatas menurut Natsir memiliki arti yang sangat dalam dan luas lebih luas dan dalam dari perkataan-perkataan itu yang biasa kita dengar dan gunakan setiap hari." Menyembah Allah" itu melengkapi semua ketaatan dan ketundukan kepada semua perintah ilahi yang membawa kepada kebesaran dunia dan kemenangan diakhirat, serta menjauhkan diri dari segala larangan yang menghalangi tercapainya kemenangan di dunia dan di akhirat itu.

Selain itu, Muhammad Natsir sangat konsen terhadap Pendidikan anak dalam Islam, sesuai yang dipahami Natsir, pada dasarnya adalah menjadi tanggung jawab ibu-bapak (orang tua). Hukumnya fadlu 'ain. Karena anak, dalam pandangan Islam, adalah amanat bagi keduanya yang harus dididik dan dipimpin. Keduanya bertanggungjawab atas anak-anak mereka. Hal ini sesuai dengan firman Allah:

${ }^{9}$ Abuddin Nata, Tokoh-Tokoh Pembaruan Pendidikan Islam di Indonesia (Jakarta: PT. Raja Grafindo Persada, 2005). 
"Hai orang-orang yang beriman, peliharalah dirimu dan keluargamu dari api neraka." (Q.S.At-Tahrim: 6)

Menurut Muhammad Natsir, maksud ayat ini adalah: "harus kita berikan kepada anak dan istri kita didikan yang memeliharanya dari dari kesesatan dan memberi keselamatan kepadanya di dunia dan akhirat. Sabda Rasulullah SAW: "Tiada seorang bayipun yang lahir melainkan dilahirkan di atas fitrah. Lalu kedua orang tuanyalah yang menjadikannya Yahudi, Majusi, atau Nashrani." (HR. Bukhari)

Mengurus pendidikan anak-anak orang Islam bukan hanya menjadi fardlu 'ain bagi orang tuanya, tapi juga menjadi fadlu kifayah bagi tiap-tiap anggota dalam sebuah masyarakat. Beliau dasarkan pada firman Allah QS. Ali Imran: 104

"Dan hendaklah ada diantara kamu segolongan umat yang menyeru kepada kebajikan, menyuruh kepada yang ma'ruf dan mencegah dariyang munkar; mereka adalah orang-orang yang beruntung."

Kaum muslimin wajib mengadakan satu kelompok yang mengadakan pendidikan untuk anak-anak orang Islam, supaya pendidikan mereka tidak di'garap' oleh orang-orang yang tidak sehaluan, tidak sedasar, tidak seiman, dan tidak seagama.hal ini sesuai dengan perintah Allah:

"Sebagian besar Ahli Kitab menginginkan agar mereka dapat mengembalikan kamu kepada kekafiran setelah kamu beriman, karena dengki yang (timbul) dari diri mereka sendiri. (QS al Baqarah: 109)

\section{c). Kurikulum Pendidikan Islam}

Menurut pandangan Mohammad Natsir kurikulum pendidikan dapat disusun dan dikembangkan secara integral dengan mempertimbangkan kebutuhan umum dan kebutuhan khusus sesuai dengan potensi yang dimiliki oleh peserta didik, sehingga akan tertanam sikap kemandirian bagi setiap peserta didik dalam menyikapi realitas kehidupannya. Beliau sangat tegas menolak teori dikotomi ilmu yang memisahkan antara ilmu agama dan ilmu umum. Hal ini tentunya sesuai dengan pandangan al-Qur'an tentang manusia. Bahwa manusia adalah makhluk yang memiliki unsur jasmani dan rohani, fisik dan jiwa yang memungkinkan ia diberi pendidikan. Selanjutnya manusia ditugaskan untuk menjadi khalifah muka bumi sebagai pengamalan ibadah kepada Allah dalam arti seluas-luasnya. Ia tidak akan bisa melaksakan tugas ini sebaik-baiknya kecuali dengan penguasaan yang baik terhadap kedua ilmu ini. 
Muhammad Natsir juga mengenalkan konsep tauhid sebagai dasar Pendidikan. Tauhid harus menjadi dasar berpijak setiap muslim dalam melakukan segala kegiatannya, diantaranya pendidikan. Muhammad Natsir juga menggariskan bahwa tauhid haruslah dijadikan dasar dalam kehidupan manusia, diantaranya dalam masalah pendidikan. Pendidikan Islam adalah pendidikan yang diasaskan pada tauhid. Beliau berpandangan bahwa pendidikan tauhid harus diberikan kepada anak sedini mungkin, selagi masih muda dan mudah dibentuk, sebelum didahului oleh materi dan ideologi dan pemahaman lain. Supaya ia memiliki tali Allah untuk bergantung. Hasil dari pendidikan model ini akan melahirkan generasi-generasi yang memiliki hubungan kuat dengan penciptanya serta mengutamakan mu'amalah sesama makhluk. Dan inilah dua syarat wajib untuk mendapatkan keselamatan dan kebahagiaan hidup, lahir dan batin. Hal ini sesuai dengan firman Allah swt dalam surat Ali Imran:112

Mereka diliputi kehinaan di mana saja mereka berada, kecuali jika mereka berpegang kepada tali (agama) Allah dan tali (perjanjian) dengan manusia, dan mereka kembali mendapat kemurkaan dari Allah dan mereka diliputi kerendahan. yang demikian itu......... (QS. Ali Imran: 112)

Menurut Natsir, meninggalkan dasar tauhid dalam pendidikan anak merupakan kelalaian yang amat besar. Bahayanya, sama besarnya, dengan penghianatan terhadap anak-anak didik. Walaupun sudah dicukupkan makan dan minumnya, pakaian dan perhiasannya, serta dilengkapkan pula ilmu pengetahuan untuk bekal hidupnya. Semua ini, menurutnya, tidak ada artinya apabila meninggalkan dasar ketuhanan (ketauhidan) dalam pendidikan mereka. Natsir memandang bahwa lahirnya para intelektual muslim yang menentang Islam dan kelompok yang western-minded adalah akibat dari pendidikan yang tidak berbasis agama yang benar. Dari sinilah beliau melihat sisi pentingnya tauhid sebagai dasar dari pendidikan Islam $^{10}$.

\section{d). Metode Pendidikan Islam}

Muhammad Natsir telah menempatkan dirinya untuk berada di jalan da'wah. Sehingga apapun yang dijalankan selalu disebatikan dengan misi da'wah.

\footnotetext{
${ }^{10}$ Badru Tamam, Konsep Pendidikan Mohammad Natsir. Lihat http://voaislam.com/teenage/print/2009/07/09/187Konsep-PendidikanMohammad-Natsir/Diakses,08 MEI 2021.
} 
Kecerdasan yang ada pada pada diri beliau dan kuatnya keyakinan terhadap ajaran islam menjadikannya seorang penda'wah yang ulung. Dan kelebihan yang dimilikinya adalah mampu berda'wah dalam berbagai aspek, seperti politik, pendidikan, keilmuan, keperibadian dan tingkah laku. Selain itu objek da'wah yang disentuh tidak hanya untuk kalangan atau golongan tertentu, namun yang menjadi target da'wah adalah mencakup seluruh masyarakat. Baik golongan atas maupun golongan bawah, bahkan kiprahnya dalam da'wah mulai dari daerah, nasional hingga internasional. Dalam berda'wah di arena politik Pak Natsir terkenal dengan dua kalimat "berda'wah dijalur politik berpolitik dijalur da'wah". Bagi Pak Natsir berpolitik adalah suatu medan da'wah, sehingga dalam prakteknya harus dilakukan dengan penuh kejujuran, keikhlasan dan sopan santun. Dalam berpolitik sangat tidak pantas kalau hanya menurutkan hawa nafsu dan menepikan hukum Allah. Berpolitik bukan untuk mencari kekuasaan tetapi yang sangat utama adalah mengutamakan kemaslahatan umat.

Begitu juga dalam dunia pendidikan, menurutnya pendidikan merupakan sarana untuk berda'wah. Dengan menggunakan kurikulum pendidikan yang integral maka proses transformasi ilmu pada peserta didik dapat ditempuh melalui tiga tingkatan yaitu: metode hikmah, mauidzah dan mujadalah. Ketiga metode tersebut bersifat landasan normatif dan diterapkan dalam tataran praktis yang dapat dikembangkan dalam berbagai model sesuai dengan kebutuhan yang dihadapi peserta didik. Dalam pandangan Natsir, dari beberapa metode yang diungkapkan di atas, terlihat metode hikmah lebih berorientasi pada kecerdasan dan keunggulan. Metode ini memiliki cakupan yang sangat luas, meliputi kemampuan memilih saat yang tepat untuk melangkah, mencari kontak dalam alam pemikiran guna dijadikan titik bertolak, kemampuan memilih kata dan cara yang tepat, sesuai dengan pokok persoalan, sepadan dengan suasana serta keadaan orang yang dihadapi. Natsir menambahkan bahwa implikasi metode hikmah ini akan menjelma dalam sikap dan tindakan.

Metode-metode tersebut diatas sesuai dengan firman Allah Ta'ala dalam surat an Nahl ayat125:

Serulah (manusia) kepada jalan Tuhan-mu dengan hikmah dan pelajaran yang baik dan bantahlah mereka dengan cara yang baik. Sesungguhnya Tuhanmu dialah yang lebih mengetahui tentang siapa yang tersesat dari jalan-Nya dan dialah yang lebih mengetahui orang-orang yang mendapat petunjuk. (QS. An Nahl:125)

Hikmah menurut pandangan Natsir memiliki beberapa kategori. Pertama, hikmah dalam arti 'mengenal golongan', yaitu bagaimana seorang da'i dalam hal ini pendidik menyikapi corak manusia (peserta didik) yang akan dijumpainya. 
Masing-masing golongan manusia harus dihadapi oleh yang sepadan dengan tingkat kecerdasan, sepadan dengan alam fikiran dan perasaan serta tabiat masing-masing. Ayat di atas mengandung petunjuk pokok bagi Rasul dan para muballighin tentang bagaimana cara menyampaikan da'wah kepada manusia yang berbagai jenis itu. M. Natsir menukil pendapat Syaikh Muhammad Abduh yang membagi hikmah dalam tiga golongan: a) ada golongan cerdik cendekiawan yang cinta kebenaran, dan dapat berfikir secara kritis, cepat dapat menangkap arti persoalan. Mereka ini harus dipanggil dengan hikmah, yakni dengan alasan-alasan, dengan dalil dan hujjah yang dapat diterima oleh kekuasaan akal mereka. b) Ada golongan awam, orang kebanyakan yang belum dapat berfikir secara kritis dan mendalam, belum dapat menangkap pengertian yang tinggi-tinggi. Mereka ini dipanggil dengan mau'idzah al-hasanah, dengan anjuran dan didikan, yang baik-baik, dengan ajaran-ajaran yang mudah difaham. c) Ada golongan yang tingkat kecerdasannya di antara kedua golongan tersebut, belum dapat dapat dicapai dengan hikmah, akan tetapi tidak sesuai pula, bila dilayani seperti golongan awam; mereka suka membahas sesuatu, tetapi tidak hanya dalam batas yang tertentu, tidak sanggup mendalam benar. Mereka ini dipanggil dengan mujadalah bi al-lati hiya ahsân, yakni dengan bertukar fikiran, guna mendorong supaya berfikir secara sehat, dan satu dan lainnya dengan cara yang lebih baik ${ }^{11 .}$

Adapun mau'idzah al-hasanah dan mujadalah bi al-lati hiya ahsân, kedua hal ini menurut Natsir lebih banyak mengenai bentuk da'wah, yang juga dapat dipakai dalam menghadapi semua golongan menurut keadaan, ruang dan waktu. Bentuk mujadalah, bertukar fikiran berupa debat, bisa dan tepat juga dipakai dalam menghadapi golongan cerdik pandai; bertukar fikiran berupa soal jawab yang mudah dapat dipakai juga dalam menghadapi golongan awam. Semua golongan ini memiliki unsur akal dan unsur rasa. Yang berbeda-beda ialah saat, keadaan dan suasana ${ }^{12}$.

\section{e.) Aktualisasi Pemikiran Mohammad Natsir dalam Pendidikan di Indonesia}

Undang-Undang Sisdiknas no.20 tahun 2003 bab I tentang ketentuan umum menyebutkan, bahwa pendidikan adalah usaha sadar dan terencana untuk memiliki kekuatan spiritual keagamaan, pengendalian diri, kepribadian,

\footnotetext{
${ }^{11}$ Mohammad Natsir, Fiqhud Da'wah. (Jakarta:Media Da'wah, 1988).

${ }^{12}$ Saeful Rokhman, Analisa terhadap buku Fiqhud Da'wah karya Mohammad Natsir. Jurnal Da'wah. Accessed 0805 2021. www.jurnalstidnatsir.co.ccl
} 
kecerdasan, akhlak mulia, serta keterampilan yang diperlukan dirinya, masyarakat, bangsa dan negara.

Pendidikan nasional dalam undang-undang tersebut diartikan sebagai pendidikan yang berdasarkan Pancasila dan Undang-Undang Dasar Negara Republik Indonesia tahun 1945 yang berpacu pada nila-nilai agama, kebudayaan nasional Indonesia dan tanggap terhadap tuntutan perubahan zaman. Sementara sistem pendidikan nasional adalah keseluruhan komponen pendidikan yang saling terkait secara terpadu untuk mencapai tujuan pendidikan nasional ${ }^{13}$.

Sedangkan yang dimaksud dengan tujuan pendidikan nasional dalam Sisdiknas adalah berkembangnya potensi peserta didik agar menjadi manusia yang beriman dan bertakwa kepada Tuhan Yang Maha Esa, berakhlak mulia, sehat, berilmu, cakap, kreatif, mandiri dan menjadi warga negara yang demokratis serta bertanggung jawab ${ }^{14}$.

Dari pengertian pendidikan, pendidikan nasional serta tujuan pendidikan nasional, sangat terasa nilai-nilai agamanya. Pada bab-bab lainnya juga sangat tampak bahwa kata agama dan nilai-nilai agamanya sering mengikuti. Hal ini menunjukkan bahwa agama menduduki posisi yang sangat penting dan tidak dapat dipisahkan dalam membangun manusia seutuhnya.

Merupakan hal yang wajar jika pendidikan nasional berlandaskan pada nilai-nilai agama, sebab bangsa Indonesia merupakan bangsa beragama.

Pendidikan menurut undang-undang tersebut juga sejalan dengan pemikiran yang dikemukakan oleh Natsir tentang pendidikan yang integral. Sistem pendidikan di Indonesia saat ini sudah memadukan antara pendidikan agama dan pendidikan umum, meskipun tidak semua lembaga pendidikan memadukan antara keduanya.

Pelajaran agama sekarang sudah diajarkan di sekolah-sekolah negeri, dimana sistem pendidikan seperti ini belum ditemukan pada zaman kolonial Belanda. Karena pada zaman dahulu, pendidikan dalam sekolah belum merupakan suatu bentuk pendidikan umum, melainkan hanya sekedar untuk memenuhi kebutuhan pegawai gubernur ${ }^{15}$.

\footnotetext{
13 Ibid

${ }^{14}$ Undang-Undang Sisdiknas, tahun 2003 bab II pasal 2 tentang dasar fungsi dan tujuan

${ }^{15}$ Karel A.S, Pesantren Madrasah Sekolah. (Jakarta:Dharma Aksara Perkasa,1986)
} 
Demikian dengan sekolah Islam dan pesantren yang sekarang sudah menambahkan pelajaran umum dalam kurikulumnya. Hal ini berbeda dengan zaman kolonial Belanda, pada saat itu sekolah Islam dan pesantren mengambil jalan sendiri, lepas dari gubernur dan tetap berpegang pada tradisinya. Sehingga sistem pendidikan Islam terpisah dari sistem pendidikan Belanda maupun sistem pendidikan yang dilaksanakan oleh Departemenn Pendidikan dan Kebudayaan Indonesia ${ }^{16}$.

Sebagai contoh konkrit dari pelaksanaan pendidikan yang bernuansa integral adalah munculnya lembaga pendidikan formal yang berdasarkan keagamaan seperti SD Islam, SMP Islam dan SMA Islam. Jadi siswa tidak hanya diajarkan tentang pengetahuan umum saja tapi juga dibarengi dengan pengetahuan agama. Sehingga siswa diharapkan cerdas secara intelektual dan spiritualnya.

Sekolah Islam terpadu juga merupakan sekolah yang diseleggarakan dengan memadukan secara integrativ nilai dan ajaran Islam dalam bangunan kurikulum. Sekolah Islam terpadu berdiri dengan mengacu kepada konsep pendidikan beberapa tokoh, salah satunya ialah Muhammad Natsir.

Contoh lain yaitu pendidikan yang dilaksanakan di pesantren-pesantren modern. Umumnya pesantren-pesantren modern di Indonesia menerapkan pendidikan yang mengintegrasikan pendidikan agama dan pendidikan umum. Selain diajarkan tentang ibadah, fiqih dan pengetahuan agama lain, para santri juga diajarkan pengetahuan umum, seperti fisika, matematika, biologi, dan sebagainya. contoh ada Ponpes Darunnajah, Gontor, Daar El-Qolam, La Tansa, Tebuireng, Al-khairaat, dan masih banyak lagi pesantren modern di Indonesia yang menintegrasikan antara pendidikan agama dan pendidikan umum.

Dapat dilihat bahwa sekolah-sekolah yang menerapkan pendidikan integral, biasanya jauh lebih maju dan modern. Hal ini tidak lain karena pendidikan intelektual dan spiritual yang bersenyawa dalam satu sistem yang integral dan terpadu, dimana terdapat ketiga asas pendidikan: kognitif, psikomotorik dan afektif yang berintegrasi dan menyatu.

${ }^{16} \mathrm{Ibid}$ 


\section{Kesimpulan}

Dari paparan tentang konsep pendidikan Islam dengan mengkaji pemikiran pendidikan Muhammad Natsir sebelumnya, maka dapat disimpulkan bahwa:

1. Konsep pendidikan Islam menurut pemikiran Muhammad Natsir dapat dilihat dari pengertian pendidikan menurut Natsir, tujuan pendidikan Islam, kurikulum pendidikannya serta metode yang beliau gunakan dalam pendidikan Islam.

2. Konsep Muhammad Natsir tentang pendidikan Islam yang universal-integral adalah merupakan ijtihad dan renungan yang digali dari Al-Qur'an dan Sunnah. Konsep pendidikan Islam secara integral yang dikemukakan oleh Natsir adalah berdasarkan tauhid, dan bertujuan untuk menjadikan manusia yang mengabdi kepada Allah dengan misi kebahagiaan di dunia dan di akhirat. Konsep pendidikan yang dibawa Natsir tidak hanya demi kepentingan duniawi saja, akan tetapi bagaimana kehidupan duniawi tersebut dapat memberikan aset untuk kehidupan di akhirat kelak.

3. Aktualisasi pemikiran muhammad natsir dalam pendidikan di indonesia dapat dilihat dari sekolah-sekolah negeri dan sekolah Islam atau pesantren saat ini, dimana Pelajaran agama sekarang sudah diajarkan di sekolah-sekolah negeri, begitu juga dengan pelajaran umum yang sudah mulai diajarkan di sekolah Islam atau pesantren. Sebagai contoh konkrit dari pelaksanaan pendidikan yang bernuansa integral adalah munculnya lembaga pendidikan formal yang berdasarkan keagamaan seperti SD Islam, SMP Islam dan SMA Islam. Jadi siswa tidak hanya diajarkan tentang pengetahuan umum saja tapi juga dibarengi dengan pengetahuan agama. Sehingga siswa diharapkan cerdas secara intelektual dan spiritualnya.

\section{Referensi}

Djaini, A. (1996). Pemikiran dan Perjuangan Mohammad Natsir. Jakarta: Pustaka Firdaus.

Husaini, A. (2010). Muhammad Natsir:Pahlawan Pendidik Teladan.

Republika. Jalaluddin. 2003. Teologi Pendidikan. Jakarta: PT. Raja Grafindo

Persada.

Nata, A. (2005). Tokoh-tokoh Pembaruan Pendidikan Islam di Indonesia. Jakarta: Grafindo Persada.

Natsir, M. (1973). Capita Selekta, jilid I \& II. Jakarta: Bulan

Bintang. Natsir, M. (1988). Fiqhud Da'wah. Jakarta: Media Da'wah.

Natsir, M. (2008). Kapita Selekta I. Jakarta: Yayasan Bulan Bintang Abadi \& Media 17 
Da'wah.

Nizar, R. d. (2005).Ensiklopedi Tokoh Pendidik Islam;Mengenal tokoh Pendidikan Islam di Indonesia. Quantum Teaching.

Rokhman, S. (2010). Analisa Terhadap Buku Fiqhud Da'wah karya Mohammad Natsir. Jurnal Dakwah. Accessed 0805 2021. www.jurnalstidnatsir.co.ccl

Rosidi, A. (1990). Sebuah Biografi. Jakarta: Gimukti Pusaka.

Steenbrink, Karel A. 1986. Pesantren Madrasah Sekolah. Jakarta: Dharma Aksara Perkasa

Tamam, B. Konsep Pendidikan Mohammad Natsir. Lihat http://voaislam.com/teenage/print/2009/07/09/187Konsep-PendidikanMohammad-Natsir/Diakses,08 MEI 2021.

Undang-Undang Sisdiknas tahun 2003 bab II pasal 2 tentang dasar fungsi dan tujuan. 